\title{
THE LEARNING EXPERIENCES OF FOREIGN LANGUAGE STUDENTS IN A CULTURE TRIP
}

\author{
Martha Nandari Santoso \\ E-mail: marthanandari@gmail.com \\ Universitas Kristen Satya Wacana
}

\begin{abstract}
This study examined the learning experiences of students of English as a Foreign Language in a culture trip that was conducted within the students' own multicultural society (Indonesia). The culture trip was aimed at providing the students with hands-on experience to learn about cross-cultural adjustment, skills to relate to people of other cultures, to be independent, and to act responsibly. Those skills are parts of the skills that people need to perform in the 21 st century environments. The study was guided by a research question: what were the students' learning experiences during the culture trip? The qualitative data for answering the research question were collected from the students' individual written reports of the trip, and the results of open-ended questionnaires given after the trip. The findings showed that for many of the students, the trip was their first independent travel experience which provided not only cross-cultural adjustment learning experience but also learning lessons about many of the skills needed in the 21 st century such as communication, using information technology, being self-directed, independent and responsible, managing goals and time, collaboration and working in a team. The study may be useful for teachers of language who would like to provide cross-cultural experiences and soft skills to the students to function effectively in 21 st-century environments.
\end{abstract}

Keywords: authentic learning activities; cross-cultural adjustment; 21 st century skills

\begin{abstract}
Abstrak: Penelitian ini membahas tentang pengalaman belajar pembelajar Bahasa Inggris sebagai Bahasa Asing melalui perjalanan budaya yang dilakukan dalam masyarakat multikultural mahasiswa sendiri (Indonesia). Perjalanan budaya ini bertujuan untuk memberikan kepada para mahasiswa pengalaman langsung untuk belajar tentang penyesuaian lintas budaya, keterampilan untuk berhubungan dengan orang-orang dari budaya lain, untuk menjadi mandiri, dan untuk bertindak secara bertanggung jawab. Keterampilan itu adalah bagian dari keterampilan yang perlu dimiliki di abad ke-21. Studi ini dipandu oleh pertanyaan penelitian: apa pengalaman belajar mahasiswa selama perjalanan budaya? Data kualitatif untuk menjawab pertanyaan penelitian diambil dari laporan perjalanan tertulis para mahasiswa, dan hasil kuesioner terbuka yang diberikan setelah perjalanan. Temuan menunjukkan bahwa bagi banyak mahasiswa, perjalanan budaya ini adalah pengalaman perjalanan independen pertama mereka yang tidak hanya memberikan pengalaman belajar tentang penyesuaian lintas budaya tetapi juga pengalaman belajar tentang berbagai keterampilan yang diperlukan di abad ke-21 seperti komunikasi, menggunakan teknologi informasi mandiri, bertanggung jawab, mengelola tujuan dan waktu, kolaborasi dan bekerja dalam tim. Studi ini dapat bermanfaat bagi guru bahasa yang ingin memberikan pengalaman lintas budaya dan soft skill kepada siswa agar dapat berfungsi secara efektif di lingkungan abad ke-21.
\end{abstract}


Kata Kunci: Kegiatan pengajaran otentik; penyesuaian lintas budaya; keterampilan abad 21

\section{INTRODUCTION}

To prepare students and graduates to face the increasingly complex life and work requirements of the 21 st century, teachers need to equip them not only with theoretical learning and knowledge but also some soft skills and practice of the application of knowledge in real-life situations. One type of learning activities that can facilitate the implementation of knowledge and the acquiring of soft skills is authentic learning activities which are defined as activities that resemble real-life problems and situations (Diamond, Middleton, \& Mather, 2011; Lombardi, 2007). The specific authentic learning activity under this study was a culture trip that was offered in an EFL class at the English Language Education program of a private university in Central Java, Indonesia. This culture trip was one of the major projects in a course called Language, Culture, and Identity (LCI) offered at semester five. The trip was meant " to provide hands-on experience on cross-cultural adjustment and develop necessary skills to relate to people from other cultures" (Sinanu, LCI course pack semester 2/ 2017-2018). Initially, an international culture trip experience, which many works of literature have shown to encourage cross-cultural learning (DeLong. et al., 2009; Lee, 2011; Cretu, 2017) was planned to be given, however due to the constrained circumstances of the students, a culture trip within the students' multicultural societies (Indonesia) was conducted. Data were gathered from the students' trip reports and questionnaires. Besides for my class evaluation, studies on a culture trip for local students conducted in one's own country instead of the more common international culture trips abroad, have not been widely done. Therefore this study may be useful for future planning of similar trips and may give ideas for providing an alternative cultural experience to students who may not be able to afford culture trips abroad.

\section{LITERATURE REVIEW}

In discussing a culture trip as an activity in a course, it is useful to understand about authentic learning activities principles which serve as the framework of this culture trip. Authentic learning activities are characterized by their resemblance to real-life problems and situations with a learning environment that looks like the application or discipline in the real-world (Diamond, Middleton, \& Mather, 2011; Lombardi, 2007). They are not only concerned with the learning content, but " authentic learning intentionally brings into play multiple disciplines, multiple perspectives, ways of working, habits of mind, and community" (Lombardi, 2007, p. 2). They link the classroom and reality (Ozverir et al., 2017). Lave and Winger (1991) describe authentic learning as learning by doing rather than from instructional teaching. Other researchers characterize authentic learning as learning from a discovery process (Schank et al., 1994), and that is gained through experience (Heath, \& McLaughlin, 1994).

Some researchers have acknowledged the values of using authentic learning activities. Kreber et al. (2007, p.24) argue the importance of authenticity in teaching as "to make individuals more whole, more integrated, more fully human, more aware, more content with their personal and professional lives, their actions more clearly linked to purpose, "empowered," better able to engage in community with others, and so forth". The presence of continuous inquiry and thinking skills in authentic learning (Rule, 2006), and problem-solving skills (Risko, Osterman, \& Schusster, cited in 
Kocygit, \& Cembat, 2013), are two other benefits of the use of authentic learning. Other studies also indicate that in authentic learning activities, students find the learning relevant and meaningful for their life, enjoyable and thus motivating (Fitzsimmons, \& Lanphar, 2011). In line with this, Lombardi (2007, p.2) stated, "Activities that involve problems of real life will enable the learners to learn by doing instead of learning by listening which educators believe to be motivating for students." Students will not only learn facts through memorization, but they will come into the classroom with their experiences, knowledge, beliefs, and interests that they gain through the authentic activity (Mehlinger, 1995 cited in Kocyigit \& Zembat, 2013). Authentic learning helps students bring their experiences, knowledge, beliefs, and interests into the classroom. This learning enables them to experiment with and use the knowledge they have constructed rather than to merely memorize facts (Mehlinger, 1995 cited in Kocyigit \& Zembat, 2013).

Despite the scarcity of literature in domestic culture trips to support the study of EFL learners, some ideas in the survey of the benefits of field trips to a cultural institution /museum done by researchers at the University of Arkansas (Greene, Kisida, \& Bowen, 2014), may provide some insights. The study showed significant impacts on students not only on their education but also on their critical thinking. In the experimental study, students were paired based on their similarities in grade level and other demographic factors and then the "treatment group" was given a tour to the museum while the 'control group' was given a deferred tour later time. Both groups were measured their critical thinking skills by asking them to write an essay about a painting they had never seen before. Researchers found that the 'treatment group' showed higher critical thinking skills compared to the 'control group.' Students coming from small cities, students from high - poverty schools, and minority students showed two to three times larger of the effects.

A study of the learning experiences of senior travelers done by Roberson (2003) showed that "learning how to travel and negotiate the complicated details of travel takes the 'student' beyond operational learning to become more confident about maneuvering independently in today's world." (p.129). Participants mentioned, "that they have learned more about other cultures, religions, and groups of people" (p.141). This kind of skill belongs to one of the 21 st-century skills that leaders in education and business have formulated to be trained to and acquired by students and graduates in the 21 st century.

The 21st-century skills consist of four categories: a). Learning and innovation skills, b). Information, media and technology skills, c). Life and career skills, and d). Social and cross-cultural skills (21st Century Knowledge and Skills in Educator Preparation, 2010). Learning and innovation skills include critical thinking, communication, collaboration, and creativity (the four Cs); Information, media, and technology skills are comprised of the ability to use, manage and evaluate information, analyze and create media and apply technology effectively; Life and career skills are among others the skills to adapt to change, to be flexible and interact effectively in multi-cultural environments, to have initiatives, to manage goals and time, to work independently, to be self-directed learners, to be able to work in a team effectively, to demonstrate leadership and to be responsible; Social and cross-cultural skills covers skills to interact effectively and work effectively in cross-cultural settings (21st Century Knowledge and Skills in Educator Preparation, 2010, appendix B).

Concerning skills in 21st century, the ability to adjust cross-culturally is undoubtedly essential. "Cross-cultural adjustment is generally defined as -the process of adaptation to living and working in a foreign culture" ( $\mathrm{Li} \&$ Sano, 2013, p.156). It 
may also be defined as" the process of "getting comfortable" with living and working in a culture different from one's home culture. " (Beil, E., \& Mayor, D.G, 2018).

It is an attempt of people from differing cultural backgrounds to adjust themselves in similar or different ways among themselves to interact across cultures (LI, 2016). Ward and Searle (1991) categorized cross-cultural adjustment in two groups: psychological and socio-cultural cross-cultural adjustment. Factors such as personality, changes of life, and support from other people influence the psychological cross-cultural adjustment, whereas general cultural knowledge, length of stay, and some interactions with people of different cultures influence the social-cultural cross-cultural adjustment (Roysircar \& Frey, 2003 cited in Li \& Sano, 2013).

The goal of the culture trip was" to provide hands-on experience on cross-cultural adjustment and develop necessary skills to relate to people from other cultures" (Sinanu, LCI course pack semester 2/ 2017-2018). Specific goals of the program were to (a) provide cultural experiences which were different from their own, (b) develop crosscultural adjustment and ability to interact with others effectively (c) work independently, and (d) act responsibly. To achieve the goals, this culture trip was designed as a two day, one-night trip from the campus location of the students in a small city, Salatiga, in Central Java Province, to Surabaya, the capital city of East Java Province which is about 350 kilometers away. In comparison, Salatiga is a small city with less than 185,000 population (http://www.citypopulation.info/php/indonesia-admin.php?adm2id=3373), and Surabaya is the second populous city in Indonesia which is according to the 2015 census the population is 3,457,404 (http://worldpopulationreview.com/worldcities/surabaya-population/). Students took the trip by train in a group of two to five, but each student was responsible for arranging their transportation (taking road transport to the train station, buying train tickets, etc.) and accommodation (booking a hotel). The dates of the travel were decided to be Saturday and Sunday. Unlike usual school trips where transportation and accommodation and all programs are arranged by the department or at least by a committee, this culture trip required students' responsibility of their travel arrangement and program to maximize their learning experiences. Students were given the freedom to explore the city, the culture and learn things on their own accord. The only arranged programs were a visit to the House of Sampoerna (a museum) ended with a dinner at a hotel hosted by the department, and a scavenger hunt task to familiarize themselves with the new environment and culture that was done in a group (See figure 1). 


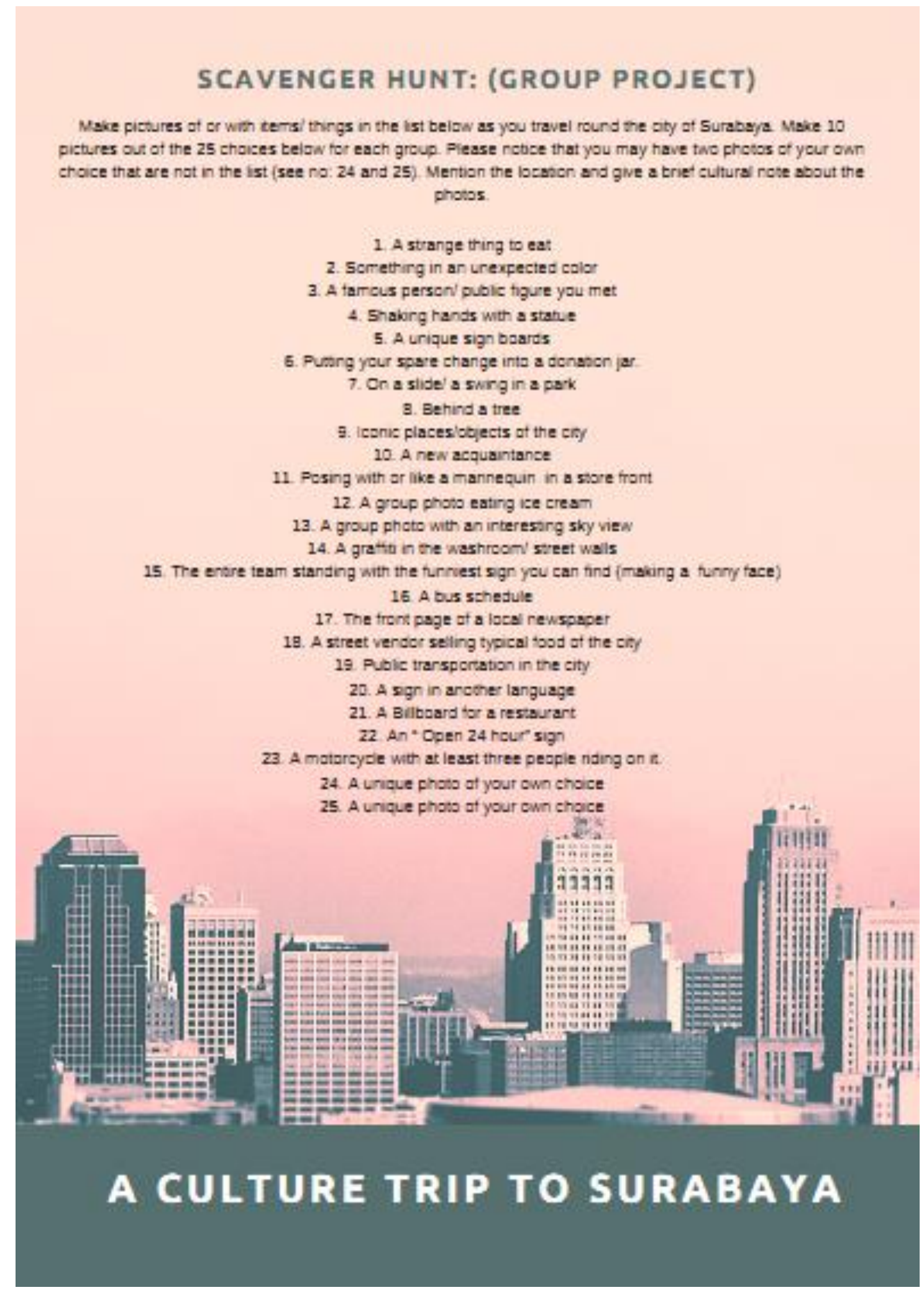

Figure 1: Scavenger Hunt Task (content adapted from https://id.pinterest.com/cat6745/scavenger-hunt-ideas/)

Twenty-two students of the English Language Education program of a private university in Salatiga, Central Java, aged 19-21 from various cultural backgrounds were involved in this culture trip study. Instead of using complete names they were coded with initials. They came from small cities in Central Java (mostly), Papua, Ambon, and 
Borneo. In this study, the students were put into six groups consisting of two to four students.

Although students were responsible for their trip, the department did some precautions for their safety and security by providing travel insurance to every student and by connecting them through a WhatsApp group. A letter of the trip description, objectives, and the lecturer's contact details were also provided for the parents. Whereas for the department, a letter of consent from the students' parents was also prepared so that parents could sign the letter as a formal statement that they allowed their child to join the trip.

\section{METHOD}

This qualitative study was to answer the research question: What were the EFL students' learning experiences through a culture trip? Twenty students from LCI class semester 2/ 2017 - 2018 at the English Language Education (ELE) of a private university in Central Java, Indonesia were involved in the study. The qualitative data for answering the research questions were collected from the students' individual written reports of the trip, and the results of an open-ended questionnaire given after the trip. To process and analyze the data, I used the procedure suggested by Craven, J., \& Griffiths, J. R. (2011). First I familiarized with the data by reading and re-reading until I could form ideas or themes. Then I coded the data based on issues that emerged from the data collected.

\section{FINDINGS AND DISCUSSION}

First of all, how the authentic learning principles were implemented in the culture trip was summarized in table 1 below.

Table 1: The Implementation of the Authentic Learning Activities Principles in the Culture Trip

\begin{tabular}{lll}
\hline No & \multicolumn{1}{c}{$\begin{array}{c}\text { Authentic Learning Activities } \\
\text { Principles }\end{array}$} & \multicolumn{1}{c}{ The Implementation in the Culture Trip } \\
\hline 1 & Real -World problems & $\begin{array}{l}\text { In the culture trip, students managed their trip, } \\
\text { did interact with people of other cultures, } \\
\text { adjusted themselves to the new environment }\end{array}$ \\
\hline 2 & Multiple disciplines & $\begin{array}{l}\text { The trip involved not only language learning, but } \\
\text { also managing money and time, working with IT, } \\
\text { travel details, etc. }\end{array}$ \\
\hline $3 \quad$ Link Classroom and reality & $\begin{array}{l}\text { Theory in class related to language, culture, and } \\
\text { identity to be applied in real experience during } \\
\text { the trip. }\end{array}$ \\
\hline $4 \quad \begin{array}{l}\text { Leaning by doing instead of by } \\
\text { instruction, learning from experience, } \\
\text { a discovery process }\end{array}$ & $\begin{array}{l}\text { Students learned and discovered learning through } \\
\text { the process of real practice and experience in the } \\
\text { trip. }\end{array}$ \\
\hline
\end{tabular}

The learning experiences of the students through the culture trip was discussed in the following. 
Even though the culture trip was a short and ordinary out-of-town trip by economy train, it turned out to be an extraordinary experience for the students. Apparently, for many of the students, it was their first time experience to use the public bus, first time to go to Surabaya, first time to take a train, first time to stay at a hotel, and first independent travel experience. One student even mentioned that this trip was her first experience to be far away from her parents. She said in her report, "This trip taught me how unpredictable the world out there was; From this trip, I could imagine how it was life outside my comfort zone and it added my viewpoint of how to live in a new environment" (Questionnaire, Student LVN). In the era which is marked by fast mobility, being able to live outside the comfort zone, and traveling experience, especially one's ability to arrange and manage an independent trip, are essential skills needed to cope with the complex requirements of life and career in the 21 st century.

The 21 st century is often called a century of information technology. It is also dubbed the century of cities where "the world is experiencing 'smart cities' boom" (Han \& Hawken, 2018, p.1). As mentioned earlier, the twenty-two students in this study came from small cities in Central Java (mostly), two came from Papua, one came from Ambon, and one came from Borneo. For many of them, the culture trip was their first experience to go to big cities. With this demographic background, going to a big city such as Surabaya enabled them to learn about and familiarize themselves with the culture of a city and its people. Students reported that they learned city culture through its physical representatives such as the technological infrastructure, skyscrapers, big luxurious malls and hotels, and the big gap of the cost of living compared to the one in Salatiga or their hometown. Students also gained some understanding about Surabaya culture by finding out the meaning behind some cultural artifacts such as statues, bridges, and other Surabaya iconic objects/ places.

Another critical learning was about the use of digital technology as a part of city life. Starting with the preparation of the trip, students learned how to book a hotel and buy train tickets online. At the train station in Semarang (the nearest train station from the campus location of the students), students printed the tickets using the self-service printing machine, which was also a part of modern city life. They also learned to use a google map for exploring the city (Surabaya). And at that time, when online taxies were only available in big cities, students tried using the online application for ordering cabs, food and other services for the first time during the trip. In the hotel, students learned about modern facilities such as vending machines and the use of a digital key which functions as a door-key, access to lifts, and a power controller. All these are empowering knowledge and IT skills which would be useful for enhancing their life and career in today's modern life worldwide.

Students learned to interact with people of other cultures within their group as well as people they met on their trip. Within their groups who mostly were from central Java, they had group members coming from either Papua, Ambon, or Borneo. Traveling together for two or three days, gave them the opportunity to adjust one from another. "I learned to understand and adjust one another" (Questionnaire, Student SFT). During the trip, students learned to adjust themselves to be accepted well. For example, in the BRT (Transit Rapid Bus), they learned to be polite and tolerant. One student said, "I gave my seat to the older people in the bus" (Report, Student WJYT). They also learned to refuse politely when many off-line taxi drivers altogether offered their services in the train station. A student described the situation by saying " I learned to survive in an uncomfortable situation" (Report, Student GFT). They also experienced getting lost in Surabaya and had to ask some local people for the direction. A student said, " We can 
not rely $100 \%$ on the technology (GPS/Google map), so I also asked the local people about the direction" (Questionnaire, Student SFT).

To communicate effectively, students managed to adjust themselves with the communication style in Surabaya which they noticed to be different. They picked up some vocabulary which marked the dialects of Surabaya and compared them with Semarang's (in Central Java) dialect such as the following:

Surabaya's dialect
'tah'
'temen'
'gak ono'
'arek'
'melok'
fast- pace speech

\author{
Semarang's dialect \\ 'to' \\ 'banget' \\ 'rak ono' \\ '(wong)' \\ '(melu)' \\ slow- pace speech
}

\author{
(The Writer's translation in English) \\ an exclamation \\ an intensifier/ very \\ there is none \\ person \\ go along (with) \\ (Report, Student GFT).
}

The positive experience of the students in the culture trip had developed their appreciation of the national identity and pride. The made a point about public transportation in their reports and questionnaires as they compared the service of public transportation to the fare they had to pay. "The (city) bus was very cheap; We only paid 1,000 rupiahs because we brought our student identity card" (Report, Student VNA). Students also appreciated the punctuality, comfort, and cleanliness of the train. One student commented, " ... the train was good, comfortable and cheap; This added my pride to be Indonesian." (Questionnaire, Student BAP). The pleasant trip by economy train was beyond their expectation as one of them said, "Unpredictably, the economy train called "..." was very comfortable and clean" (Report, Student GFT). The various culinary they tried in Surabaya and the different dialect they learned during their stay and interaction with the people in Surabaya also brought their awareness of the richness of the culture in Indonesia. One student mentioned, " My experience eating special culinary in Surabaya added my pride for Indonesia: I tried soto lamongan and sate klopo which tasted very uniquely delicious " (Questionnaire, Student BAP). Another student felt proud of the richness of the dialects. He said, "I feel prouder of the culture of my own country which is so various, and yet we are one; such as the dialect in Surabaya, for example, is so different from the dialect in Central Java" (Questionnaire, Student WW). Thus, upon their exploration during the trip, they had a better image of their own country (Indonesia).

The scavenger hunt task (see figure 1) which was done in a group seemed to be useful in encouraging collaboration among the students. The responsibility to make ten pictures out of the twenty-five options provided, with the limited time they had, required them to plan, and organize the task among the members so that they could complete the work on time. Students also collaborated to remind one another to manage the time and plan the schedule so that they could make use the best of their time to enjoy the trip.

Students admitted that their experience with the self-arranged trip trained them to be self-directing, and manage their time and money well. "I learned many things about life (living) in this trip. I also learned how to manage my money ... and become an independent person" (Report, Student ND). "I learned how important (it was) to manage the time well" (Report, Student NCD). " I learned to manage my money and not to spend for unnecessary things, and this trip also taught me to value my time and use it wisely" (Questionnaire, Student ND). Their success and enjoyment of the trip gave them the courage to conduct other trips of their own. Students said: "This trip has developed my confidence and independence. If someday in my work I have to travel 
alone, I already had the experience of arranging my travel. So I will not become a burden to other people" (Questionnaire, Student BKL). "Next time, I will visit another place to enrich my knowledge about the differences (of) culture from many places" (Report, Student DK).

When students find the learning relevant and meaningful for their life learning will be enjoyable and motivating (Fitzsimmons, \& Lanphar, 2011). Students described their experiences of this culture trip with phrases such as "awesome experience", "will never forget", "amazing impressing trip", "enjoyed the trip", want another trip", happy to join the trip", "great experience" and other similar expressions that showed enjoyment of what they did. At the same time, they also gained a lot of learning experiences as described earlier in this discussion section.

The 21st-century skills learned through the culture trip could be summarized in table 2 below:

Table 2: The 21st-century skills learned through the culture trip

\begin{tabular}{lll}
\hline No & \multicolumn{1}{c}{ The 21st Century Skills } & \multicolumn{1}{c}{ The Culture Trip Learning Experiences } \\
\hline 1 & $\begin{array}{l}\text { Communication, adaption to change, } \\
\text { and being flexible. }\end{array}$ & $\begin{array}{l}\text { Students learned to adjust one another with their } \\
\text { multicultural friends in the group. } \\
\text { Students learned to be well accepted when } \\
\text { interacting with the local people in Surabaya by } \\
\text { adjusting their communication style with their } \\
\text { dialect. }\end{array}$ \\
\hline 2 & $\begin{array}{l}\text { The use of digital information } \\
\text { technology. }\end{array}$ & $\begin{array}{l}\text { Students used online applications to book train } \\
\text { tickets, hotel rooms, taxies, and other services. } \\
\end{array}$ \\
& $\begin{array}{l}\text { Students used a google-map, digital keys at the } \\
\text { hotel, self-service machines, and other } \\
\text { technological facilities. }\end{array}$ \\
\hline 3 & $\begin{array}{l}\text { Managing goals and time, being self- } \\
\text { directed, independent and } \\
\text { responsible. }\end{array}$ & $\begin{array}{l}\text { Students managed their trips and planned their } \\
\text { program. }\end{array}$ \\
\hline 4 & $\begin{array}{l}\text { Collaboration, teamwork, and } \\
\text { leadership. }\end{array}$ & $\begin{array}{l}\text { Students worked collaboratively to complete the } \\
\text { group project (the Scavenger Hunt Task) and } \\
\text { practiced leadership in managing their group } \\
\text { work. }\end{array}$ \\
\hline
\end{tabular}

\section{CONCLUSION}

The culture trip was overall a fun and happy learning experiences for the students. They described the trip with positive phrases such as "awesome experience", "will never forget", "amazing and impressing trip", "enjoyed the trip," want another trip", happy to join the trip", "great experience" and other phrases showing enjoyment. They learned about arranging details of their trip such as managing time and money, booking a ticket and a hotel online, ordering a taxi using an online application, using a google map for getting the direction, and other necessary skills for functioning well in this mobile environment. They also learned the new culture in Surabaya and experienced interaction with people of different cultures, which required them to be polite and tolerant and to adjust their communication style with the locals as to be accepted well. The trip experience also gave them the opportunity to develop both their independence and ability to collaborate with others. The fact that this culture trip was self-arranged by the individual students was the strength of this trip design. In this way, students were conditioned to be independent and self-directing. And the success of their trip developed 
their confidence/self-efficacy to make a trip of their own in the future. In this way, their learning has become self-directing, autonomous and continuous education. All these skills are essential skills to live in 21 st-century environments. The disadvantages of this kind of activity are the time consumption and financial preparation. Nevertheless, compared to international culture trips that are commonly provided for EFL crosscultural adjustment training, this domestic culture trip could function as an alternative with much more affordable resources in particular for students in constrained circumstances.

Teachers of foreign languages who would like to provide cross-cultural experiences and soft skills to the students to function effectively in the $21 \mathrm{st}$-century environments could adopt this kind of culture trip. The essential element of the culture trip is the selfarranged travel which requires the students to arrange their transportation, accommodation, and exploration program responsibly. In this way students would have the opportunity to learn many of the skills needed in the 21 st century such as communication, using information technology, being self-directed, independent and responsible, managing goals and time, collaboration and working in a team. In circumstances where an international culture trip is affordable, cross-cultural adjustment training could be more challenging.

\section{ACKNOWLEDGMENT}

I would like to thank Frances Sinanu, M.A, a senior lecturer at the English Language Education, Faculty of Language and Arts, Universitas Kristen Satya Wacana (UKSW), Salatiga, Indonesia, who coordinated the parallel classes of the Language, Culture and Identity course in Semester 2/ 2017-2018 at UKSW, of which direction, this culture trip was conducted.

\section{REFERENCES}

Beil, E., \& Mayor, D.G. 2018. The Challenge of Cross-Cultural Adjustment. Master's Thesis. Department of Management and Engineering, Linkoping University.

Craven, J., \& Griffiths, J. R. 2011. Data Analysis. In Grant, M. J., Sen, B., \& Spring, H. (Eds.), Research Evaluation and Audit : Key Steps in Demonstrating Your Value (pp.145-175). Retrieved from http://ebookcentral.proquest.com Created from ukswebooks on 2018-12-17 23:45:01

Cretu, D. 2017. Fostering 21st Century Skills for Future Teachers. Edu World 2016, 7Th International Conference paper. http://dx.doi.org/10.15405/epsbs.2017.05.02.8

DeLong, M., et al. 2009. Cultural Exchange: Evaluating an Alternative Model in Higher Education. Journal of Studies in International Education 20 (10) 1-17. doi:10.1177/1028315309334619

Diamond, S., Middleton, A., \& Mather, R. 2011. A Cross-Faculty Simulation Model for Authentic Learning. Innovations in Education and Teaching International, 48(1), $25-35$.

Fitzsimmons, P., \& Lanphar, E. 2011. When there's Love inside there's a Reason Why: Emotion as the Core of Authentic Learning in One Middle School Classroom. Literacy Learning in the Middle Years, 19(2), 35-40.

Greene, J. P., Kisida, B., \& Bowen, D. H. 2014. The Educational Value of Field Trips. Education Next_14 (1), $78-86$

Han, H., Hawken, S. 2018. Introduction: Innovation and Identity in Next-generation smart Cities. City, Culture and Society 12, 1-4 
Heath, S. B., \& McLaughlin, M. W. 1994. Learning for anything every day. Journal of Curriculum Studies, 26(5), 471-489. Doi: 10.1080/0022027940260501.

KOÇYİĞITa, S., Zembat, R. 2013. The Effects of Authentic Tasks on Preservice Teachers' Attitudes towards Classes and Problem Solving Skills. Educational Sciences: Theory \& Practice 13(2), 1045-1051.

Kreber, C., Klampfleitner, M., McCune, V., Bayne, S., \& Knottenbelt, M. 2007. What Do You Mean by "Authentic"? A Comparative Review of the Literature on Conceptions of Authenticity in Teaching. Adult Education Quarterly, American Association for Adult and Continuing Education, 58(1), 22-43.

Li, Y.X \& Sano, H. 2013. Cross-Cultural Adjustment of Chinese Students in Japan: School Adjustment and Educational Support. International Journal of Progressive Education 9 (3) 154-168

Lombardi, M.M. 2007. Authentic learning for the $21^{\text {st }}$ century: An overview. Retrieved September 25, 2018, from https://www.researchgate.net/publication/220040581_ Authentic_Learning_for_the_21st_Century

Ozverir, I., Osam, U. V., \& Herrington, J. 2017. Investigating the effects of authentic Activities on foreign language learning: A design-based research approach. Educational Technology \& Society, 20(4), 261-274.

Partnership for 21st Century Skills. 2010. 21st Century Knowledge and Skills in Educator Preparation. Retrieved from http://www.p21.org/storage/documents/ aacte_p21_whitepaper2010.pdf

Roberson, D. N., Jr. 2003. Learning experiences of senior travelers. Studies in Continuing Education, 21(1), 125-144. https://doi.org/10.1080/01580370309288

Rule, A.C (2006). Editorial: The components of authentic learning. Journal of Authentic Learning, 3(1), 1-10. Salatiga Population 2019 http://www.citypopulation.info/php/ indonesia-admin.php?adm2id=3373 Scavenger Hunt Ideas: https://id.pinterest.com/ cat6745/scavenger-hunt-ideas/)

Schank, R. C., Fano, A., Bell, B., \& Jona, M. 1994. The Design of Goal-Based Scenarios. Journal of the Learning Sciences, 3(4), 305-345. Doi: 10.1207/s15327809j1s0304_2

Sinanu, F. 2017. Language, Culture, and Identity (Course Pack). Salatiga: English Language Education Program, Universitas Kristen Satya Wacana. Surabaya Population 2019 retrieved 31 January 2019 from http://worldpopulationreview.com/ world-cities/surabaya-population/

Ward, C., \& Searle, W. 1991. The Impact of Value Discrepancies and Cultural Identity on Psychological and Sociocultural Adjustment of Sojourners. International Journal of Intercultural Relations, 15(2), 209-225. http://dx.doi.org/10.1016/0147-1767 (91)90030-K 